\title{
Co-Digestion of Orange Pulp and Cattle Manure with Different C/N Ratios and A New Modeling of Biogas Production
}

\author{
M. Raşit ATELGE
}

\begin{abstract}
In this study, the co-digestion of orange pulp (OP) and cattle manure (CM) were investigated. The anaerobic process (40 d) of five reactors prepared according to different carbon to nitrogen $(\mathrm{C} / \mathrm{N})$ ratios $(17,26,29,35,43.76)$ was completed. Anaerobic digestion (AD) was investigated in batch reactors $(1000 \mathrm{~mL})$ and both biogas production measured every five days and soluble chemical oxygen demand (SCOD) value \% removals were determined. The highest biogas production was observed as $373.9 \mathrm{~mL} / \mathrm{g}$ TS in the reactor in which the $(\mathrm{C} / \mathrm{N})$ ratio was 29. Compatibility of biogas production measured every five days of all reactors was investigated by Wood model and Wilmink model. Model evaluation criteria were interpreted on the basis of coefficient of determination $\left(\mathrm{R}^{2}\right)$, sum of remaining squares (RSS), Akaike information criterion (AIC) and Bayesian information criterion (BIC) tests. As a result, except for other studies, biogas production measured in anaerobic processes (every 5 days) was successfully completed according to Wood and Wilmink models.
\end{abstract}

Keywords: Biofuels, Biogas, C/N ratio, Wood model, Wilmink model.

\section{Portakal Posasının ve Sığır Gübresi Farklı C/N Oranlarına ile Birlikte Parçalanması ve Biyogaz Üretiminde Yeni Bir Modelleme}

\section{$\ddot{\mathbf{O z}}$}

Bu çalışmada, portakal posası (OP) ve sığır gübresinin $(\mathrm{CM})$ birlikte sindirimi incelenmiştir. Farklı karbon azot (C/N) oranlarına $(17,26,29,35,44)$ göre hazırlanmış beş reaktörün anaerobik süreci (40 d) tamamlanmıştır. Anaerobik parçalama (AP) kesikli reaktörlerde $(1000 \mathrm{~mL})$ incelenmiş ve her iki biyogaz üretimi her beş günde bir ölçülmüş ve \%SCOD değeri giderimi belirlenmiştir. C/N oranının 29 olduğu reaktörde en yüksek biyogaz üretimi $373.9 \mathrm{~mL} / \mathrm{g}$ TS olarak gözlemlendi. Tüm reaktörlerin beş günde bir ölçülen biyogaz üretiminin Wood modeline ve Wilmink modeline uyumu araştırılmıştır. Belirleme katsayısı $\left(\mathrm{R}^{2}\right)$, kalan kareler toplamı (RSS), Akaike bilgi kriteri (AIC) ve Bayesian bilgi kriteri (BIC) testleri baz alınrak model değerlendirme kriterleri yorumlanmıştır. Sonuç olarak, diğer çalışmalar haricinde anaerobik proseslerde ölçülen biyogaz üretimi (5 günde bir ) Wood ve Wilmink modellerine göre başarıyla tamamlanmıştır.

Anahtar Kelimeler: Biyoyakıtlar, Biyogaz, C/N oranı, Ahşap model, Wilmink modeli. 


\section{Introduction}

The growing population has increased the energy demand in the last century. The production of energy to meet this incremental demand pushes human beings to find sustainable and renewable energy sources because traditional energy production from fossil fuels cause irreversible damages to the earth such as global warming and climate change. Renewable energy systems (RES) can include solar, wind, hydro, geothermal, and biomass. Among them, biomass energy has caught the attention of policy makers and researchers due to two major benefits which are energy security and waste management in the last two decades (Atelge et al., 2021). Biomass energy can be produced through anaerobic digestion (AD) methods which are defined where organic waste resources can be converted into methane as an energy carrier and carbon dioxide in an oxygen-free environment by microorganisms (Atelge, 2021). AD is a way to produce bio-methane and bio-hydrogen which are forms of renewable energy. Developed countries including many European counties are the leaders for biogas production and its utilization according to their established biogas facilities. In Europe, the biogas production facilities increased from 6,227 to 18,943 between 2009 and 2019 (EBA, 2020). If this growth rate remains, it is projected that biogas production may reach an equivalent of $467 \mathrm{TWh}$ by 2030 and 1,020 TWh by 2050 (EBA, 2020). Feedstocks for AD process have been heavily studies in the literature; however, there are still some gaps for usage different agricultural waste such as orange waste.

Although orange production is concentrated in the Mediterranean region, more than 6 million tonnes are collected each year in Spain, Italy, Greece and Portugal (Negro et al., 2017). About 30\% of this production takes place in Italy, which produces bulky waste flows of about 0.6 million tonnes of orange waste (Ferrari et al., 2016). The orange waste constitutes about 50-60\% by weight (wet weight) of the processed fruit and the shell of 60-65\% by weight, 30-35\% by weight of the inner tissue and the share of the remaining seeds (Crawshaw, 2003). Numerous promising suggestions for the use of this waste are described in the literature (Ángel Siles López et al., 2010). Orange industry wastes are generally applied in many areas in the form of orange peels and orange straws. Studies on the production of biogas from orange wastes have been investigated in two different categories such as orange straw or orange shells (Calabrò et al., 2018; Wang et al., 2019).

Ortiz-Sanchez et al. (Ortiz-Sanchez et al., 2020) reported biogas production from orange peel waste as a mono substrate after applying pectin extraction process. Their result revealed that $0.256 \mathrm{~N}$ $\mathrm{m}^{3} / \mathrm{g}$ TS of biogas was obtained from orange peel waste. In another study, orange waste (pulp and peel) with ensuing aerobic after treatment of the digestate was utilized for AD under thermophilic condition. In batch assays, methane production amount of approximate $0.49 \mathrm{~m}^{3} \mathrm{~kg}^{-1} \mathrm{VS}$ added waste was obtained (Kaparaju \& Rintala, 2006). Wikandari et al. (Wikandari et al., 2015) reported that AD 
of the orange shells yielded biogas production at a value of $61-217 \mathrm{~mL} / \mathrm{g}$ VS. The most acceptable and easy method for improvement of biogas production is co-digestion strategy.

Co-digestion is a waste treatment method where different wastes are mixed and processed together (Ağdağ \& Sponza, 2007; Şenol, 2020b). Anaerobic co-digestion of orange peel wastes and jatropha de-oiled cake for biogas production were carried out on the batch scale $(500 \mathrm{~mL})$ under anaerobic condition at ambient temperature (in various mixing ratios of two substrates). The experimental data showed a highest biogas output of $1140 \mathrm{~mL}$ of gas production at (1:2) ratio of jatropha deoiled cake with orange peel waste obtained for a period of 17 days (Elaiyaraju \& Partha, 2012). Another study was reported that orange peel and catering waste were investigated the codigestion effect on biogas yield (Anjum et al., 2017). The biogas production was increased 1.5 times when a 1:1 mixing ratio of orange peel and catering waste was used (Anjum et al., 2017). One of the most abundant feedstocks for the AD process is daily manure which is widely used. Even though daily manure is abundant, its nutrition levels are very low for the AD process, so that, the biogas and methane yields are lower. To overcome this issue, co-digestion should be done with another organic material (Alonso et al., 2016). In the literature, co-digestion was applied to poultry manure and orange peel with different mixing ratios under the mesophilic condition at the batch reactor (Lami \& Chimdessa, 2017). The result revealed that the highest cumulative biogas production was obtained to be $768 \mathrm{~mL}$ that was 3.5 times higher than $100 \%$ orange peel when the mixing ratio was $75 \%$ poultry manure and $25 \%$ of orange peel (Lami \& Chimdessa, 2017). This result showed that the co-digestion strategy is important for orange waste because the carbon to nitrogen ratio $(\mathrm{C} / \mathrm{N})$ in the reactor can be adjusted with this strategy.

The $\mathrm{C} / \mathrm{N}$ ratio should be in a range between 16/1 and 45/1 for hydrolysis, and 20/1 and 30/1 for methanogenesis. If the $\mathrm{C} / \mathrm{N}$ ratio is high, methanogenic bacteria quickly consume the available nitrogen for their cell synthesis, and carbon utilization will be limited. Therefore, the degradation process could stop. If the ratio is too low, nitrogen is converted to ammonia, which is inhibitory for $\mathrm{AD}$ because $\mathrm{pH}$ is increased in the reactor (Atelge et al., 2020b).

To maximize bioenergy recovery from waste, the optimization of the AD process is an essential step such as using co-substrates to balance nutrient level. Moreover, the modelling of the AD process is a crucial topic to understand the process and improvement of bioenergy production. In the literature, there are various models, with the most acceptable being the logistic growth curve and the modified Gompertz model, which have been created to clarify the AD process (Özarslan et al., 2021). The aim of this study is to investigate the co-digestion of orange pulp (OP) and cow manure (CM) with different mixing ratios with the $\mathrm{AD}$ process. Five different mixing ratios are used based on $\mathrm{C} / \mathrm{N}$ values as $17,26,29,35,44$. Furthermore, to understand the synergistic effect of co-digestion, two new modeling approaches, Wood and Wilmink model, are applied to biogas production. 


\section{Materials and Methods}

\subsection{Preparation of Organic Wastes and Anaerobic Digestion Setup}

Orange pulp (OP) and cow manure (CM) at different mixing ratios were used as feedstocks for co-digestion. Orange was collected from an agriculture farm in Antalya. OP was obtained as waste after the juicing process. CM was used as a co-substrate was obtained from an animal farm in Samsun. $\mathrm{CM}$ was passed through the shredder before use, and it was ensured that the material diameter was around 1-2 $\mathrm{mm}$. The characterizations of OP and CM are presented in Table 1.

$1000 \mathrm{~mL}$ flasks with a $600 \mathrm{~mL}$ working volume were used as a reactor for the AD process. The $\mathrm{AD}$ process was taken place at $55 \pm 2{ }^{\circ} \mathrm{C}$ as the thermophilic condition. The dry matter content was fixed at $9 \%$ for all reactors. Moreover, the reactors were connected to gas collector bags. The produced biogas volume was determined with the water displacement method every 5 days. The produced biogas was measured with the water displacement method. The produced biogas was stored in a bag as seen in Figure 1. The volume of biogas was determined every 5 days to transfer to a measuring cylinder that was full of water. In this way, the volume was determined.

The AD process can be divided into four main steps, which are namely hydrolysis, acidogenesis, acetogenesis, and methanogenesis. Depending on substrate types, either hydrolysis or methanogenesis is the rate-determining process for AD. If the substrate has a more complex structure, hydrolysis becomes the limiting step while methanogenesis is the rate-determining step if substrate is easily broken down (Passos et al., 2017). Hydrolysis takes place within a few hours for carbohydrates, a few days for proteins and lipids, and several days for lignin and lignocellulose (Atelge et al., 2020b). Moreover, the digestion process cannot be fully completed if the substrate has high lignin and lignocellulose (Atelge et al., 2020a). Therefore, the hydrolysis phase can generally be accepted as the rate-determining step because microorganisms produce several kinds of hydrolytic enzymes and they are not sufficient to break down the substrate's highly complex structure (Atelge et al., 2020b). Applying new model for biogas production needs a meaningful difference between intervals. Therefore, the produced biogas volume was determined with the water displacement method every 5 days. $\mathrm{CM}$ and $\mathrm{OP}$ were mixed with different ratios for the anaerobic digestion process. After the mixing process, five $\mathrm{C} / \mathrm{N}$ ratios in the reactors were obtained as 17, 26, 29, 35, and 44. $\mathrm{AD}$ process for each mixing ratio was run triplicate. To remove oxygen from the bottle and establish anaerobic conditions, nitrogen was flushed into each bottle for $5 \mathrm{~min}$ before they were tightly sealed with a stopper. Figure 1 shows the AD test setup. The inoculum used in experiments was derived from a wastewater treatment plant (Samsun East Advanced Biological Wastewater Treatment Plant). The volatile solids (VS), total solids (TS), and SCOD values of the inoculum used were 9.8, 5.1, and 
$1877 \mathrm{mg} \mathrm{O}_{2} / \mathrm{L}$, respectively. The inoculum/substrate ratio of all reactors was set at 1.0 on a TS basis. Additionally, to determine soluble chemical oxygen demand (SCOD) removal, the sample was taken from each reactor every 5 days. AD process was concluded about 40 days.

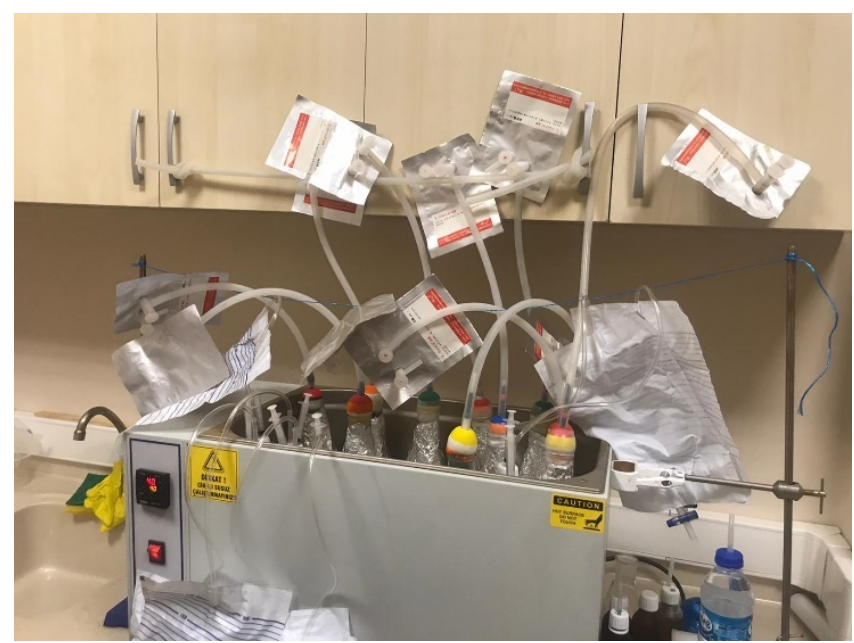

(a)

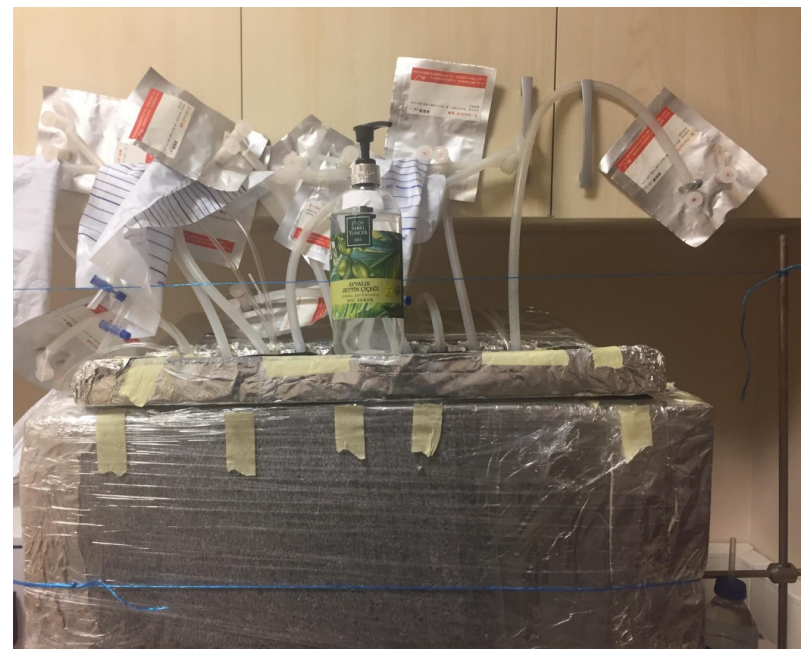

(b)

Figure 1. Anaerobic digestion test setup (a) before start, (b) during AD process

\subsection{Analytical Methods}

Volatile solids (VS), total solids (TS), moisture, SCOD, carbon-nitrogen ratio $(\mathrm{C} / \mathrm{N}), \mathrm{pH}$, cellulose, hemicellulose and lignin analyze were performed before starting AD to organic waste. TS and VS were analyzed according to standard method 2540 (APhA, 1988). Cellulose, hemicellulose and lignin were measured using fiber analyzer (Van Soest et al., 1991). The $\mathrm{C} / \mathrm{N}$ ratio of the lignocellulosic substrates was determined by the Costec elemental analyzer. With the elemental analysis, the sample was burn with dry air. During the combustion, exhaust gases were determined as $\mathrm{CO}_{2}, \mathrm{H}_{2} \mathrm{O}, \mathrm{SO}_{\mathrm{x}}$, and $\mathrm{NO}_{\mathrm{x}}$. According to these gases, the combinations of substrates can be determined as $\mathrm{C}, \mathrm{H}, \mathrm{S}$, and $\mathrm{N}$. The $\mathrm{O}$ content was deduced by difference. The moisture content of substrate was deduced by difference of TS. Liquid samples were centrifuged at 9,000 rpm for $45 \mu \mathrm{m}$ membrane filter. Thus, SCOD analyzes were performed according to closed reflux method (cod closed reflux titrimetric method) (Astm, 2002). The analysis results are given in Table 1. As a result of all experiments, the amount of biogas produced was determined as $\mathrm{mL}$ biogas volume per gram total solid by deducting the yield of the inoculum. 
Table 1. Characteristics of organic raw materials

\begin{tabular}{|c|c|c|}
\hline Parameters & $\mathbf{C M}$ & $\mathbf{O P}$ \\
\hline TS ( w/w \%) & $19.70 \pm 0.1$ & $17.41 \pm 0.1$ \\
\hline VS (TS \%) & $85.80 \pm 0.09$ & $79.95 \pm 0.08$ \\
\hline Moisture ( w \% ) & $80.30 \pm 0.09$ & $82.59 \pm 0.09$ \\
\hline$\%$ C ( w/w \% ) & $29.13 \pm 0.25$ & $45.95 \pm 0.25$ \\
\hline$\% \mathrm{~N}(\mathrm{w} / \mathrm{w} \%)$ & $1.72 \pm 0.05$ & $1.05 \pm 0.05$ \\
\hline $\operatorname{SCOD}\left(\mathrm{mg} \mathrm{O}_{2} / \mathrm{L}_{\text {slurry }}\right)$ & $29,680 \pm 85$ & $8968 \pm 56$ \\
\hline $\mathrm{C} / \mathrm{N}$ & 17 & 44 \\
\hline $\mathrm{pH}$ & $6.81 \pm 0.01$ & $3.75 \pm 0.01$ \\
\hline Cellulose ( w/w \% ) & $24.09 \pm 3.0$ & $15.82 \pm 3.1$ \\
\hline Hemicellulose ( w/w \% ) & $17.12 \pm 1.8$ & $7.23 \pm 1.6$ \\
\hline $\operatorname{Lignin}(\mathrm{w} / \mathrm{w} \%)$ & $9.85 \pm 2.8$ & $3.95 \pm 2.2$ \\
\hline
\end{tabular}

\subsection{Data Analysis}

Wood and Wilmink models were carried out to perform a full analysis of all reactors. These models are called lactation curves (Janković et al., 2016). The Wood model to define the lactation curve of dairy cows proposed by Wood (1967) is one of the most common models (Sherchand et al., 1995). The Wilmink model was proposed by Wilmink (1987) (Vargas et al., 2000). Wood and Wilmink models are represented in Eq. (1) and Eq. (2), respectively.

$$
\begin{aligned}
& Y(t)=a t^{b} \exp (-c t) \\
& Y(t)=a-b \exp (-c t)-d t
\end{aligned}
$$

In this study, lactation curve models given in Eq. (1) and (2) were adapted to \% $\mathrm{CH}_{4}$ production. For all models, "a" represents production at the beginning of lactation, "b" is the inclining slope parameter up to peak production, "c" and "d" are the declining slope parameter (Silvestre et al., 2006). $\mathrm{Y}(\mathrm{t})$ is \% CH4 in lactation on day t. The parameters a, b, c, and $\mathrm{d}$ in these models were calculated from the actual values with SPSS 23.0 program. Expression of \% $\mathrm{CH}_{4}$ yields with mathematical models allows the predictability of yields along AD. The shape of the lactation curve is the criterion of total or lactation $\% \mathrm{CH}_{4}$ yield in the evaluation of $\% \mathrm{CH}_{4}$ yield.

To determine a compatible model, the statistical indicators were compared (the coefficient of determination $\left(\mathrm{R}^{2}\right)$, the residual sum of squares (RSS) (Eq. 3) (Draper \& Smith, 2014), the secondorder Akaike information criterion (AIC) test (Eq. 4) (Akaike, 1974), and the Bayesian information criterion (BIC) test (Eq.5) (Schwarz, 1978)). 


$$
\begin{aligned}
& \mathrm{RSS}=\sum_{\mathrm{k}=1}^{\mathrm{N}}\left(\mathrm{y}_{\mathrm{k}}-\widehat{y_{k}}\right)^{2} \\
& \mathrm{AIC}= \begin{cases}N \ln \left(\frac{R S S}{N}\right)+2 K, & \text { when } \frac{N}{K} \geq 40 \\
N \ln \left(\frac{R S S}{N}\right)+2 K+\frac{2 K(K+1)}{N-K-1}, & \text { when } \frac{N}{K}<40\end{cases} \\
& \mathrm{BIC}=N \ln \left(\frac{R S S}{N}\right)+\mathrm{K} \ln (\mathrm{N})
\end{aligned}
$$

where, $\mathrm{y}_{\mathrm{k}}$ is measured values, $\widehat{y_{k}}$ is estimated values, $\mathrm{N}$ is number of data point, $\mathrm{k}$ is number of model parameters.

\section{Results and Discussion}

Five different reactors $\left(\mathrm{C} / \mathrm{N}: 17\right.$ for $\mathrm{R}_{1}, \mathrm{C} / \mathrm{N}: 26$ for $\mathrm{R}_{2}, \mathrm{C} / \mathrm{N}: 29$ for $\mathrm{R}_{3}, \mathrm{C} / \mathrm{N}: 35$ for $\mathrm{R}_{4}$ and $\mathrm{C} / \mathrm{N}$ : 44 for $\mathrm{R}_{5}$ ) prepared according to different $\mathrm{C} / \mathrm{N}$ ratios were identified. The total anaerobic process took about 40 days. It was determined that the highest biogas production was obtained when the $\mathrm{C} / \mathrm{N}$ ratio was $29(373.9 \pm 4.52 \mathrm{~mL} / \mathrm{g}$ TS). In one study, the optimum value of $\mathrm{C} / \mathrm{N}$ ratio was obtained 25 (Ning et al., 2019). According to the $\mathrm{C} / \mathrm{N}$ ratios, the average methane gas production from the agricultural wastes (olive pomace, cattle manure, poultry litter, whey, and corn silage) was $239 \mathrm{~mL} \mathrm{CH}_{4} / \mathrm{g}$ VS (Valenti et al., 2018). In this study, the lowest biogas production occurred in the reactor in which the $\mathrm{C} / \mathrm{N}$ ratio was $17(315 \pm 7.89 \mathrm{~mL} / \mathrm{g} \mathrm{TS})$. As the $\mathrm{C} / \mathrm{N}$ ratio was higher than 26 , nitrogen requirement for anaerobic bacteria was found and inhibitor effect was observed. The biogas yields of the reactors with $\mathrm{C} / \mathrm{N}$ ratio: 17 and 35 were close to each other. As the $\mathrm{C} / \mathrm{N}$ ratio went from 17 to 29, biogas yield increased in $\mathrm{AD}$. As the $\mathrm{C} / \mathrm{N}$ ratio increased from 26 , biogas production slightly decreased. Therefore, it was understood that the optimum ratio among the $\mathrm{C} / \mathrm{N}$ ratios determined in the study for two different organic wastes was 29.

Figure 2 shows SCOD removal of the reactors. The anaerobic process was monitored by SCOD removal measurements. The SCOD removals of all reactors were consistent with the amount of biogas production. SCOD removal for ten reactors was between $69.9 \pm 2.37-87.5 \pm 3.87 \%$. In AD study of microalgae, SCOD removal was $69.1 \%$ (Nguyen et al., 2019b). Among the reasons why SCOD removal cannot be close to $100 \%$ may be the short duration of the process where the maximum number of anaerobic bacteria is present.

Normally, the rate of decomposition of organic matter by anaerobic bacteria was directly proportional to the rate of biogas production, so SCOD removal would have to show a curve similar to sigmoidal biogas production curves (Şenol et al., 2020). A different situation may be the result of 
experimental errors. Biogas production was slow in the first 15 days for all reactors and accelerated after 15 days. After 30 days, it started to slow down. A study carried out with OP that biogas production measured daily started to accelerate after the first 7 days (Erdogan et al., 2015). The reason for this acceleration is that there is no pretreatment, no vaccination, or late gain of resistance to $\mathrm{C} / \mathrm{N}$ ratios of microorganisms. Another possible reason is that the high cellulose content in OP is partially dissolved in water over a long period of time (Şenol, 2021).

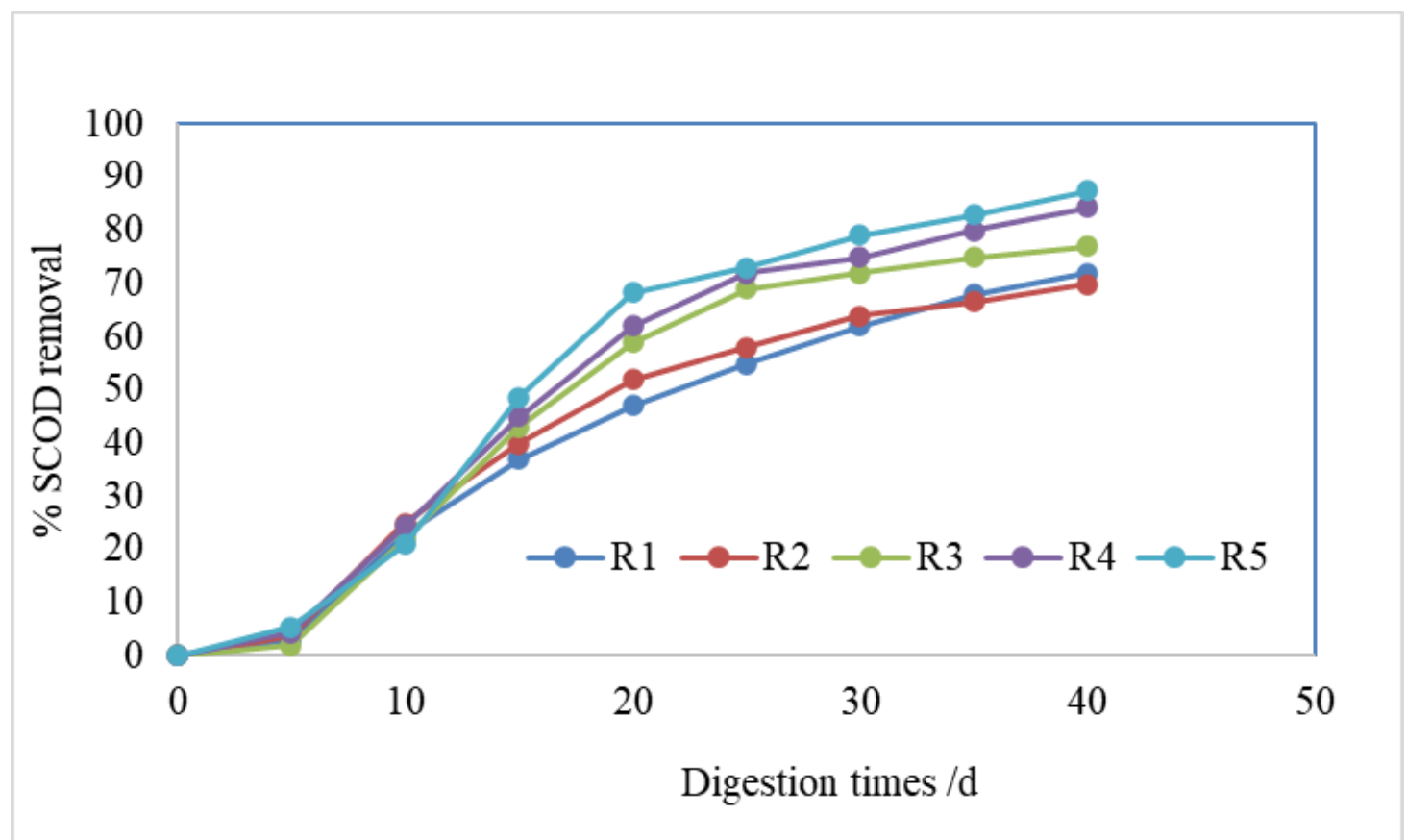

Figure 2. SCOD removed of reactors prepared according to $\mathrm{C} / \mathrm{N}$ ratios $\left(\mathrm{C} / \mathrm{N}: 17\right.$ for $\mathrm{R}_{1}, \mathrm{C} / \mathrm{N}: 26$ for $\mathrm{R}_{2}$, $\mathrm{C} / \mathrm{N}: 29$ for $\mathrm{R}_{3}, \mathrm{C} / \mathrm{N}: 35$ for $\mathrm{R}_{4}$ and $\mathrm{C} / \mathrm{N}: 44$ for $\left.\mathrm{R}_{5}\right)$.

The objective of AIC model selection is to estimate the information loss when the probability distribution $f$ related to the true model is approximated by possibility distribution $g$, related to the model that is to be evaluated (Wagenmakers \& Farrell, 2004). Detailed reporting on these model selection criterions in AD has not been found in literature. In addition, in the biogas production modeling studies, previously, Wood model and Wilmink model have not been used. The criteria parameters of RSS, $\mathrm{R}^{2}$, AIC and BIC were calculated (Table 2) and used as the main decomposers to determine a better fit of the model to the measured experimental value. The lower values of RSS, AIC, and BIC indicate a more appropriate model (Yang et al., 2016). $\mathrm{R}^{2}$ is a measure that allows us to determine how certain one can be in making predictions from a certain model. The closer the $\mathrm{R}^{2}$ value to 1 , the better the model applied (Ali et al., 2015). 
Table 2. Criteria for the analysis of the best fit of the Wood and Wilmink models to the experimental data.

\begin{tabular}{llccccc}
\hline & & $\mathbf{R}_{\mathbf{1}}$ & $\mathbf{R}_{\mathbf{2}}$ & $\mathbf{R}_{\mathbf{3}}$ & $\mathbf{R}_{\mathbf{4}}$ & $\mathbf{R}_{\mathbf{5}}$ \\
\hline \multirow{4}{*}{ Wood } & RSS & 225.963 & 185.163 & 291.384 & 287.985 & 81.777 \\
& $\boldsymbol{R}^{\mathbf{2}}$ & 0.912 & 0.945 & 0.919 & 0.896 & 0.969 \\
& AIC & 47.008 & 45.216 & 49.297 & 49.191 & 37.861 \\
& BIC & 37.797 & 36.005 & 40.086 & 39.980 & 28.650 \\
\hline \multirow{4}{*}{ Wilmink } & RSS & 134.130 & 111.475 & 140.138 & 91.221 & 36.447 \\
& $\boldsymbol{R}^{\mathbf{2}}$ & 0.948 & 0.967 & 0.961 & 0.967 & 0.986 \\
& AIC & 54.314 & 52.649 & 54.709 & 50.845 & 42.588 \\
& BIC & 35.300 & 33.635 & 35.695 & 31.831 & 23.574 \\
\hline
\end{tabular}

A value of $\mathrm{R}^{2}$ higher than 0.9 indicates that the data fit the models used mathematically (Şenol, 2020a). This study shows that biogas production from reactors was fitted with the Wood model, except the $\mathrm{R}_{4}$ reactor. The deviation of the data obtained on the $5^{\text {th }}$ day in the $\mathrm{R}_{4}$ reactor from the model curves may have decreased the $\mathrm{R}^{2}$ value. In the Wilmink model, considering the $\mathrm{R}^{2}$ evaluation criteria, it is seen that all the data successfully fit $\left(\mathrm{R}^{2}>0.9\right)$.

According to RSS and $\mathrm{R}^{2}$ values, all reactors were better suited to the Wilmink model. The most compatible reactor for the Wilmink model was $\mathrm{R}_{5}\left(\mathrm{R}^{2}=0.986-\mathrm{RSS}=36.447\right)$ and the most compatible reactor for the Wood model was $\mathrm{R}_{5}\left(\mathrm{R}^{2}=0.969-\mathrm{RSS}=81.777\right)$. According to Wood and Wilmink model, the most compatible $\mathrm{C} / \mathrm{N}$ ratios in $\mathrm{AD}$ were found to be 44 .

According to the AIC values, the $\mathrm{R}_{5}$ reactor for the Wood and Wilmink model were the most compatible reactors. The interpretations of the AIC model evaluation criteria appear to be similar to the BIC model evaluation criteria (Table 2). According to the BIC values, the all reactors were better fitted to the Wilmink model (BIC $=23.574-35.300$ ) In a previous study, the compatibility of cumulative biogas production to sigmoidal model (modified Gompertz) was discussed and the AIC value found 75.153 and the BIC value found 70.078. Similarly, the AIC value for the Cone model found 63.543 and the BIC found 58.468 (Nguyen et al., 2019a).

Figure 3 shows the curves of Wood and Wilmink models drawn according to the experimental data. The biogas production in the reactors were measured at intervals of five days, and after the first 5 days, the data ranged from $22.4 \pm 1.1 \mathrm{~mL} / \mathrm{g}$ TS to $35.6 \pm 1.2 \mathrm{~mL} / \mathrm{g}$ TS. Final (cumulative) biogas productions for $\mathrm{R}_{1}, \mathrm{R}_{2}, \mathrm{R}_{3}, \mathrm{R}_{4}$ and $\mathrm{R}_{5}$ reactors were found as $315,319,350,362.9$ and $373.9 \mathrm{~mL} / \mathrm{g}$ TS values, respectively. Generally, when all five reactors were analyzed, all reactors were well fitted to Wood and Wilmink models. 


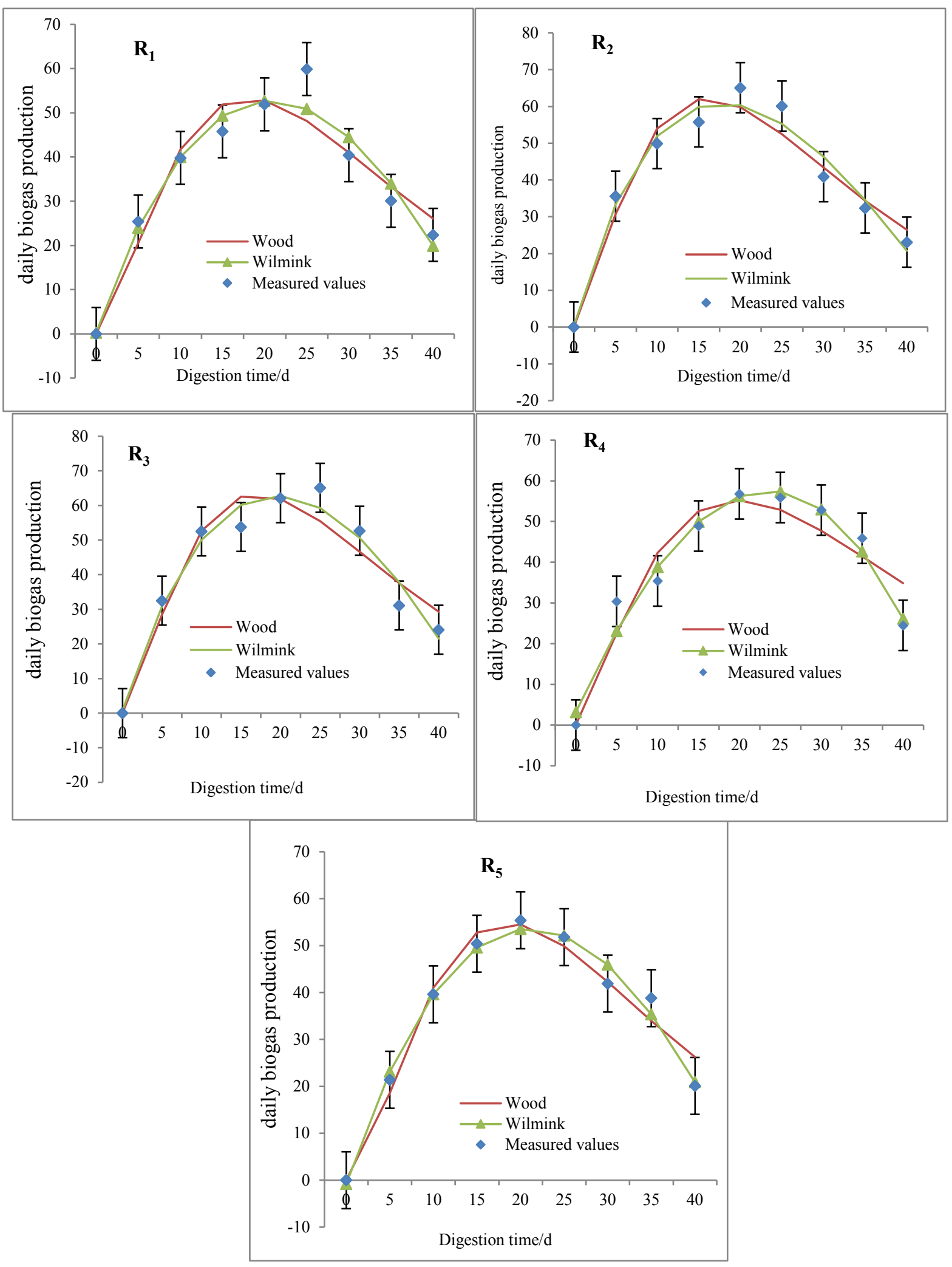

Figure 3. Compatibility of biogas production measured every five days to Wood and Wilmink model $\left(\mathrm{C} / \mathrm{N}: 17\right.$ for $\mathrm{R}_{1}, \mathrm{C} / \mathrm{N}: 26$ for $\mathrm{R}_{2}, \mathrm{C} / \mathrm{N}: 29$ for $\mathrm{R}_{3}, \mathrm{C} / \mathrm{N}: 35$ for $\mathrm{R}_{4}$ and $\left.\mathrm{C} / \mathrm{N}: 44\right)$. 


\section{Conclusions and Recommendation}

Five different reactors were determined according to carbon to nitrogen ratios of orange pulp and cattle manure and the anaerobic process of these mixtures was examined. It was concluded that the carbon to nitrogen ratios at the end of anaerobic digestion affect the microorganisms that breed in the anaerobic process. The highest biogas production was obtained to be $373.9 \pm 4.52 \mathrm{~mL} / \mathrm{g}$ TS from $\mathrm{R}_{3}$ (the carbon to nitrogen ratio:29) while the lowest biogas production as $315 \pm 7.89 \mathrm{~mL} / \mathrm{g}$ TS occurred in the $\mathrm{R}_{1}$ (the carbon to nitrogen ratio:17). Moreover, the soluble chemical oxygen demand removals of all reactors were consistent with the amount of biogas production. The soluble chemical oxygen demand removal for ten reactors was between $69.9 \pm 2.37-87.5 \pm 3.87 \%$. Additionally, RSS, $\mathrm{R}^{2}$, AIC and BIC were determined as the criteria parameters of Wood and Wilmink models. According to RSS and $\mathrm{R}^{2}$ values, all reactors were better suited to the Wilmink model. The most compatible reactor for the Wilmink model was $\mathrm{R}_{5}\left(\mathrm{R}^{2}=0.986-\mathrm{RSS}=36.447\right)$ and the most compatible reactor for the Wood model was $\mathrm{R}_{5}\left(\mathrm{R}^{2}=0.969-\mathrm{RSS}=81.777\right)$. According to Wood and Wilmink models, the most compatible carbon to nitrogen ratios in AD were found to be 44 . Thus, it was concluded that daily biogas production in anaerobic digestion could be modeled with lactation curves.

\section{Acknowledgement}

The authors would like to thank Doç. Dr. Sabit HOROZ for proofreading this paper.

\section{Statement of Conflicts of Interest}

There is no conflict of interest between the authors.

\section{Statement of Research and Publication Ethics}

The author declares that this study complies with Research and Publication Ethics.

\section{References}

Ağdağ, O.N., Sponza, D.T. 2007. Co-digestion of mixed industrial sludge with municipal solid wastes in anaerobic simulated landfilling bioreactors. J. Hazard. Mat., 140(1-2), 75-85.

Akaike, H. 1974. A new look at the statistical model identification. in: Selected Papers of Hirotugu Akaike, Springer, pp. 215-222. 
Ali, M., Eyduran, E., Tariq, M.M., Tirink, C., Abbas, F., Bajwa, M.A., Baloch, M.H., Nizamani, A.H., Waheed, A., Awan, M.A. 2015. Comparison of artificial neural network and decision tree algorithms used for predicting live weight at post weaning period from some biometrical characteristics in Harnai sheep. Pakistan J. Zool.

Alonso, R.M., del Río, R.S., García, M.P. 2016. Thermophilic and mesophilic temperature phase anaerobic co-digestion (TPAcD) compared with single-stage co-digestion of sewage sludge and sugar beet pulp lixiviation. Biomass Bioenergy, 93, 107-115.

Ángel Siles López, J., Li, Q., Thompson, I. 2010. Biorefinery of waste orange peel. Crit. Rev. Biotechnol, 30(1), 63-69.

Anjum, M., Khalid, A., Qadeer, S., Miandad, R. 2017. Synergistic effect of co-digestion to enhance anaerobic degradation of catering waste and orange peel for biogas production. Waste Management \& Research, 35(9), 967-977.

APhA, A. 1988. WPCF, 1992 Standard Methods for the Examination of Water and Wastewater, Washington. Astm, A. 2002. Standard test methods for chemical oxygen demand (dichromate oxygen demand) of water.

Atelge, M.R., Atabani, A.E., Banu, J.R., Krisa, D., Kaya, M., Eskicioglu, C., Kumar, G., Lee, C., Yildiz, Y.Ş., Unalan, S., Mohanasundaram, R., Duman, F. 2020a. A critical review of pretreatment technologies to enhance anaerobic digestion and energy recovery. Fuel, 270(January), 117494-117494.

Atelge, M.R., Krisa, D., Kumar, G., Eskicioglu, C., Nguyen, D.D., Chang, S.W., Atabani, A.E., Al-Muhtaseb, A.H., Unalan, S. 2020b. Biogas production from organic waste: recent progress and perspectives. Waste and Biomass Valorization, 11(3), 1019-1040.

Atelge, M.R., Senol, H., Djaafri, M., Hansu, T.A., Krisa, D., Atabani, A., Eskicioglu, C., Muratçobanoğlu, H., Unalan, S., Kalloum, S., Azbar, N., Kivrak, H.D. 2021. A Critical Overview of the State-of-the-Art Methods for Biogas Purification and Utilization Processes. Sustainability, 13(20), 11515-11515.

Atelge, R. 2021. Türkiye'de Sığır Gübresinden Biyoyakıt Olarak Biyogaz Üretiminin Potansiyeli ve 2030 ve 2053 Yıllarında Karbon Emisyonlarının Azaltılmasına Öngörülen Etkisi. International Journal of Innovative Engineering Applications, 5(1).

Calabrò, P., Paone, E., Komilis, D. 2018. Strategies for the sustainable management of orange peel waste through anaerobic digestion. $j$. Environ. Manage., 212, 462-468.

Crawshaw, R. 2003. Co-product feeds: animal feeds from the food and drinks industries R Crawshaw Nottingham University Press, Nottingham, 2001 pp 285, price£ 30.00 (paperback) ISBN 1-897676-352. J. Sci. Food Agric., 83(4), 362-362.

Draper, N.R., Smith, H. 2014. Applied regression analysis. John Wiley \& Sons.

EBA. 2020. European Biogas Association Annual Report 2020.

Elaiyaraju, P., Partha, N. 2012. Biogas production from co-digestion of orange peel waste and jatropha deoiled cake in an anaerobic batch reactor. Afr. J. Biotechnol., 11(14), 3339-3345.

Erdogan, E., Atila, B., Mumme, J., Reza, M.T., Toptas, A., Elibol, M., Yanik, J. 2015. Characterization of products from hydrothermal carbonization of orange pomace including anaerobic digestibility of process liquor. Bioresour. Technol., 196, 35-42.

Ferrari, A., Morone, P., Tartiu, V. 2016. Tackling Uncertainty through Business Plan Analysis-A Case Study on Citrus Waste Valorisation in the South of Italy. Agriculture, 6(1), 5.

Janković, M., Leko, A., Šuvak, N. 2016. Application of lactation models on dairy cow farms. Croat. Oper. Res. Rev., 7(2), 217-227.

Kaparaju, P.L.-N., Rintala, J. 2006. Thermophilic anaerobic digestion of industrial orange waste. Environ. Technol., 27(6), 623-633.

Lami, M., Chimdessa, M. 2017. Biogas Production from Co-Digestion of Poultry Manure and Orange Peel through Thermal Pre-Treatments in Batch Fermentation. American Scientific Research Journal for Engineering, Technology, and Sciences (ASRJETS), 38(2), 226-246.

Negro, V., Ruggeri, B., Fino, D., Tonini, D. 2017. Life cycle assessment of orange peel waste management. Resour. Conserv. Recycl., 127, 148-158.

Nguyen, D.D., Jeon, B.-H., Jeung, J.H., Rene, E.R., Banu, J.R., Ravindran, B., Vu, M.C., Ngo, H.H., Guo, W., Chang, S.W. 2019a. Thermophilic anaerobic digestion of model organic wastes: Evaluation of biomethane production and multiple kinetic models analysis. Bioresour. Technol.

Nguyen, M.-L.T., Lin, C.-Y., Lay, C.-H. 2019b. Microalgae cultivation using biogas and digestate carbon sources. Biomass Bioenergy, 122, 426-432.

Ning, J., Zhou, M., Pan, X., Li, C., Lv, N., Wang, T., Cai, G., Wang, R., Li, J., Zhu, G. 2019. Simultaneous biogas and biogas slurry production from co-digestion of pig manure and corn straw: performance optimization and microbial community shift. Bioresour. Technol. 
Ortiz-Sanchez, M., Solarte-Toro, J.-C., González-Aguirre, J.-A., Peltonen, K.E., Richard, P., Cardona Alzate, C.A. 2020. Pre-feasibility analysis of the production of mucic acid from orange peel waste under the biorefinery concept. Biochemical Engineering Journal, 161, 107680.

Özarslan, S., Abut, S., Atelge, M.R., Kaya, M., Unalan, S. 2021. Modeling and simulation of co-digestion performance with artificial neural network for prediction of methane production from tea factory waste with co-substrate of spent tea waste. Fuel, 306, 121715.

Passos, F., Ortega, V., Donoso-Bravo, A. 2017. Thermochemical pretreatment and anaerobic digestion of dairy cow manure: Experimental and economic evaluation. Bioresource Technology, 227, 239-246.

Schwarz, G. 1978. Estimating the dimension of a model. The Annals of Statistics, 6(2), 461-464.

Şenol, H. 2020a. Anaerobic digestion of hazelnut (Corylus colurna) husks after alkaline pretreatment and determination of new important points in Logistic model curves. Bioresource Technology, 300, 122660.

SSenol, H. 2021. Effects of $\mathrm{NaOH}$, thermal, and combined $\mathrm{NaOH}$-thermal pretreatments on the biomethane yields from the anaerobic digestion of walnut shells. Environmental Science and Pollution Research, 113.

Şenol, H. 2020b. Enhancement in methane yield from anaerobic co-digestion of walnut shells and cattle manure. Environmental Progress \& Sustainable Energy, 39(6), e13524.

Şenol, H., Erşan, M., Görgün, E. 2020. Optimization of temperature and pretreatments for methane yield of hazelnut shells using the response surface methodology. Fuel, 271, 117585.

Sherchand, L., McNew, R., Kellogg, D., Johnson, Z. 1995. Selection of a mathematical model to generate lactation curves using daily milk yields of Holstein cows. J. Dairy Sci., 78(11), 2507-2513.

Silvestre, A., Petim-Batista, F., Colaco, J. 2006. The accuracy of seven mathematical functions in modeling dairy cattle lactation curves based on test-day records from varying sample schemes. J. Dairy Sci., 89(5), 1813-1821.

Valenti, F., Zhong, Y., Sun, M., Porto, S.M., Toscano, A., Dale, B.E., Sibilla, F., Liao, W. 2018. Anaerobic co-digestion of multiple agricultural residues to enhance biogas production in southern Italy. Waste Manage., 78, 151-157.

Van Soest, P.v., Robertson, J., Lewis, B.J.J.o.d.s. 1991. Methods for dietary fiber, neutral detergent fiber, and nonstarch polysaccharides in relation to animal nutrition. 74(10), 3583-3597.

Vargas, B., Koops, W., Herrero, M., Van Arendonk, J.A. 2000. Modeling extended lactations of dairy cows. J. Dairy Sci., 83(6), 1371-1380.

Wagenmakers, E.-J., Farrell, S. 2004. AIC model selection using Akaike weights. Psychon. Bull. Rev., 11(1), 192-196.

Wang, D., Yang, X., Tian, C., Lei, Z., Kobayashi, N., Kobayashi, M., Adachi, Y., Shimizu, K., Zhang, Z. 2019. Characteristics of ultra-fine bubble water and its trials on enhanced methane production from waste activated sludge. Bioresour. Technol., 273, 63-69.

Wikandari, R., Nguyen, H., Millati, R., Niklasson, C., Taherzadeh, M. 2015. Improvement of biogas production from orange peel waste by leaching of limonene. BioMed Research International, 2015.

Yang, H., Deng, L., Liu, G., Yang, D., Liu, Y., Chen, Z. 2016. A model for methane production in anaerobic digestion of swine wastewater. Water res., 102, 464-474. 